\title{
TINJAUAN TERHADAP PROSES PEMBUATAN KERAJINAN ANYAM ROTAN BERDASARKAN BENTUK DESAIN DI KOTA MEDAN
}

\author{
Erwin Crismianto $^{1^{*}}$, Mesra $^{2^{*}}$ \\ Program Studi Pendidikan Seni Rupa, Jurusan Seni Rupa, Fakultas Bahasa dan Seni \\ Universitas Negeri Medan \\ E-mail : erwincrismianto@yahoo.com
}

\begin{abstract}
ABSTRAK
Penelitian ini bertujuan untuk mengetahui dan memahami proses pembuatan dan bentuk desain produk kerajinan anyam rotan di Kota Medan. Populasi yang akan dijadikan sebagai objek dalam penelitian ini adalah seluruh produk kerajinan anyam rotan di industri kerajinan anyam rotan "Yogja" yang berada di Jln..Metode penelitian yang digunakan adalah pendekatan metode deskriptif kualitatif yaitu dengan menguraikan masing-masing subjek yang akan diteliti dan disesuaikan dengan kerangka teori yang telah ditetapkan. Hasil-hasil penelitian menunjukkan, bahwa produk kerajinan anyam rotan yang diteliti berjumlah 5 (lima) produk, dibuat dengan proses pembuatan yang sama, melalui tujuh tahap, yaitu tahap pertama; proses penentuan ide produk kerajinan anyam rotan; tahap ke dua, yaitu proses pembuatan desain bentuk produk kerajinan anyam rotan; tahap ke tiga, yaitu persiapan bahan, meliputi bahan pokok dan bahan tambahan; tahap ke empat yaitu persiapan alat; tahap ke lima yaitu proses pembuatan kerangka produk kerajinan anyam rotan; tahap ke enam yaitu proses menganyam rotan; dan tahap ke tujuh yaitu proses finishing, hanya saja pada proses pembuatan produk kerajinan anyam penyekat ruangan ada sedikit perbedaannya yaitu proses membersihkan atau memutihkan rotan setelah dianyam. Pembersihan atau Pemutihan rotan bertujuan untuk menghilangkan silika (bersifat kimia).
\end{abstract}

Kata Kunci: Kerajinan, Anyaman Rotan, Proses, Desain 


\section{PENDAHULUAN}

\section{Latar Belakang Masalah}

Kerajinan anyam tradisional merupakan keterampilan masyarakat yang dalam pembuatannya masih sangat sederhana dan kerap kali diidentikkan pada hal-hal yang bersifat turun temurun serta kurang dalam pengembangannya, salah satu kerajinan tradisional ini adalah kerajinan anyam rotan di Kota Medan. Kerajinan anyam rotan merupakan salah satu kerajinan yang sudah cukup lama ada di Kota Medan, dari generasi ke generasi hingga saat ini, dan menjadi sumber penghasilan bagi masyarakat.

Seiring dengan berjalannya waktu dan berkembangnya teknologi, serta ilmu pengetahuan telah mengubah pencitraan terhadap kerajinan anyam rotan yang dihasilkan masyarakat, dan hal ini disebabkan masuknya anyaman dari bahan plastik yang kualitasnya tidak kalah dengan produk sejenisnya, dimana harganya lebih murah dan juga lebih tahan lama, yang menyebabkan berkurangnya masyarakat yang meminati kerajinan anyam rotan pada masyarakat di Kota Medan, serta akan menimbulkan pengaruh pada kemungkinan berkurangnya kuantitas dan kualitas produk kerajinan anyam rotan.

Semakin banyaknya produk anyaman rotan yang berbahan plastik masuk di kota Medan yang kualitasnya tidak kalah dengan produk sejenisnya, mengakibatkan pengrajin anyaman rotan mengalami penurunan produksi dan kurangnya minat konsumen terhadap kerajinan anyam rotan alami. Dengan kondisi ini, para pengrajin anyaman rotan alami akan mengalami gulung tikar. Jika para pengrajin tidak ingin ini semua terjadi, pengrajin harus melakukan perubahan terhadap proses produksi yang masih tradisional menjadi proses produksi dengan cara modern dan mengubah bentuk kerajinan anyaman rotan yang masih sederhana menjadi bentuk yang lebih menarik atau modern.

Proses pembuatan dan bentuk desain kerajinan anyam rotan di industri kerajinan anyam rotan "Yogja" yang terletak di Jln. Titipapan Gg. Pertama No. 15 K, Gatot Subroto, Medan, masih tergolong sederhana, dikarenakan desain pada produk kerajinan anyam rotan ini masih menggunakan pengulangan dari bentuk-bentuk desain yang sudah ada, sehingga produk yang dihasilkan pun masih sederhana dan merupakan bentukbentuk lama. Seiring dengan perkembangan ilmu pengetahuan dan teknologi, seharusnya bentuk desain pada industri kerajinan anyam rotan di Kota Medan juga harus berkembang dan desainnya pun seharusnya sudah menggunakan desain yang lebih modern, walaupun desain tersebut ada yang dibuat berdasarkan permintaan konsumen, tetapi harus dibuat lebih variatif dan kreatif lagi, agar dapat bersaing dengan produk-produk yang lain dan menarik minat para konsumen. Oleh karena itu, penulis ingin mengetahui bagaimana proses pembuatan produk kerajinan anyam rotan berdasarkan bentuk desain tersebut, 
apakah produk tersebut sudah memenuhi prinsip-prinsip desain yang akan menghadirkan nilai estetis agar meningkatkan kuantitas dan kualitas produk kerajinan anyam rotan, yang akan dibahas dalam artikel ini.

Adapun tujuan penelitian ini yaitu untuk mengetahui dan memahami proses pembuatan dan bentuk desain produk kerajinan anyam rotan di Kota Medan, khususnya di Industri kerajinan anyam rotan "Yogja", dan dari hasil penelitian yang telah dicapai, diharapkan akan memberikan manfaat sebagai acuan dan sumber informasi bagi pengrajin sebagai masukan dalam pengembangan desain produk, dan meningkatkan harga jual pada masa yang akan datang, sebagai bahan masukan bagi penikmat seni rupa, sebagai informasi bagi Mahasiswa Universitas Negeri Medan khususnya pada jurusan seni rupa tentang keanekaragaman kerajinan Indonesia, Sebagai salah satu bahan referensi bagi peneliti lain yang melakukan penelitian yang relevan, Sebagai bahan masukan kepada pihak pemerintah daerah untuk pengembangan dan pembinaan terhadap kerajinan anyaman rotan di Kota Medan, dan juga sebagai sumbangan pemikiran kepada masyarakat umum untuk dijadikan sebagai bahan pengetahuan yang diterapkan dalam membuat berbagai produk kerajinan anyam rotan.

\section{KAJIAN PUSTAKA}

\section{Pengertian Tinjauan}

Penelitian ini memerlukan
pengamatan berupa tinjauan lapangan. Adapun pengertian tinjauan Menurut Kamus Besar Bahasa Indonesia (2005 : 75) "Tinjauan adalah pemeriksaan yang teliti, penyelidikan, kegiatan pengumpulan data, pengolahan, analisa dan penyajian data yang dilakukan secara sistematis dan objektif untuk memecahkan suatu persoalan". Adapun tinjauan dalam penelitian ini adalah tinjauan terhadap produk kerajinan anyam rotan pada industri kerajinan anyam rotan "Yogja", yang berada di Jln. Titipapan Gg. Pertama No. 15 K, Gatot Subroto, Medan berdasarkan bentuk desain, proses, dan nilai estetika.

\section{Proses Pembuatan}

Dalam Kamus Besar Bahasa Indonesia (2005 : 369), dijelaskan bahwa pengertian proses adalah: "Runtunan perubahan (peristiwa) dalam perkembangan sesuatu, serta merupakan rangkaian tindakan, pembuatan, atau pengolahan yang menghasilkan produk. Dalam hal ini, proses yang dimaksud adalah rangkaian tindakan, pembuatan, atau pengolahan untuk menghasilkan produk kerajinan anyam rotan. Proses pembuatan produk kerajinan anyam rotan cukup panjang, diawali dengan cara membentuk rotan dan menyambung rotan dengan berbagai macam jenis sambungan.

\section{Pengertian Desain}

Dalam situs www.artikata.com (diakses : Kamis, 10 september 2015 pukul : 04:37), dijelaskan bahwa : “ Disegno (bahasa Italia) = design (bahasa Inggris) = desain (bahasa Indonesia). Disegno : gambar". Dalam Kamus Besar Bahasa Indonesia dijelaskan bahwa: "Desain adalah kerangka bentuk; rancangan". (KBBI, 1996 : 37). 
Desain merupakan rancangan awal untuk membuat sesuatu, menentukan pola, ukuran, dan sebagainya agar hasil akhirnya dapat tercapai sesuai keinginan. Dalam dunia seni rupa di Indonesia, kata desain kerap dipadankan dengan reka bentuk, reka rupa, perencanaan, rangka, sketsa ide, gambar, merancang, meniru gambar, pemecahan masalah rupa.

\section{Pengertian Produk}

Dalam situs www.pengertianahli.com/2014/05/pe ngertian-produk-dan-jenis-

produk.htmI?m=1 (diakses : Sabtu, 7 November 2015 pukul : 02:00), dijelaskan bahwa : "Produk adalah sesuatu yang dapat ditawarkan ke pasar untuk diperhatikan, dipakai, dimiliki, atau dikonsumsikan sehingga dapat memuaskan keinginan atau kebutuhan". Dari pengertian ini dapat disimpulkan bahwa hampir semua yang termasuk produksi adalah benda nyata yang dapat dilihat, diraba, dan dirasakan. Karena produk adalah benda riil, maka jenisnya cukup banyak. Secara garis besar jenis-jenis produk bisa dirincikan menjadi dua jenis, yaitu produk konsumsi dan produk industri.

\section{Pengertian Kerajinan Anyam}

Kerajinan adalah suatu keterampilan yang diwariskan secara turun temurun oleh nenek moyang. Kerajinan merupakan usaha manusia untuk memproduksi berbagai perabot maupun barang-barang kerajinan lain, yang didalamnya mempunyai unsur kegunaan dan sebagai pemenuh kebutuhan manusia, karena kerajinan juga merupakan suatu usaha industri, Maka dalam proses produksinya akan selalu berkaitan dengan kegiatan ekonomi.

Menurut Chairani (2012 : 6) dalam bukunya yang berjudul "Kerajinan anyam", menjelaskan bahwa : Anyaman dapat diartikan dengan setiap pekerjaan yang memakai cara silang atau susup-menyusup antara satu iratan (berupa pita, tali) ke iratan yang lain.

Kerajinan anyaman terdiri dari dua penggal kata yaitu kerajinan dan anyaman. Kerajinan berasal dari kata "rajin". Dengan kata lain, tersimpul pengertian tekun, teliti (telaten), sabar dan terampil dalam mengerjakan bentuk yang rumit. Sedangkan anyaman dapat diartikan dengan setiap pekerjaan yang memakai cara silang menyilang atau susup menyusup antara satu iratan (berupa tali, pita) ke iratan yang lain.

(Chairani, 2012: 6).

Dari dua pengertian di atas dapatlah diambil pengertian kerajinan anyam ialah: suatu kegiatan kerajinan tangan berdasarkan ketekunan, ketelitian, kesabaran dan terampil berdasarkan pikiran yang kreatif dengan cara silang-menyilang atau susup-menyusup antara iratan satu ke iratan lainnya. 


\section{Anyaman Rotan}

Menurut Margono (1992 : 5) dalam bukunya yang berjudul "Keterampilan anyaman bambu dan rotan" menjelaskan bahwa : "Rotan yang nama latinnya "Calamus sp", itu termasuk suku Nibung-nibungan (bangsa palmae).

Tumbuhan rotan ini banyak terdapat di hutan-hutan di seluruh Indonesia, terutama di Sumatera, Kalimantan, Sulawesi dan Jawa. Rotan adalah jenis "palm" yang merambat dapat tumbuh mencapai panjang 100 meter lebih, besarnya mulai $3 \mathrm{~cm}$ sampai sebesar lengan manusia dan terbungkus kulit luar yang berduri. Batang ini beruas banyak, dan kulitnya licin, mengkilat. Sifat rotan ialah pegas, elastis dan kuat”.

\section{Jenis-Jenis Rotan}

Jenis-jenis rotan yang sering digunakan oleh pengrajin anyaman rotan di industri kerajinan anyam rotan "Yogja" adalah rotan irit (Calamus Trachycoleus Beccari), rotan manau (Calamus Manan Miq), rotan batang (Daemonorops Robustus Warb), rotan cacing (Calamus Melanoloma Mart), rotan sega (Calamus Caesius Blume), dan rotan getah (Daemonorops Angustifolia Mart).

\section{Cara Penebangan Rotan}

Menurut Soedjono (1997 : 11) dalam bukunya yang berjudul "Mengolah rotan untuk barang kerajinan ekspor", menjelaskan bahwa : "Penebangan rotan sebaiknya dilakukan pada musim kemarau, karena memudahkan proses pengeringan (dengan sinar matahari). Pengeringan yang kurang baik dan lamanya tidak tepat, akan menyebabkan warna rotan kurang baik atau rusak.
Selain itu pada musim hujan batang bekas pemotongan akan rusak atau busuk, sehingga kemungkinan besar tidak dapat bertunas lagi”.

\section{Pengolahan}

Menurut Soedjono (1997 : 12) dalam bukunya yang berjudul "Mengolah rotan untuk barang kerajinan ekspor", menjelaskan bahwa : "Setelah ditebang, batang dibersihkan pelepahnya dan dipotong menurut ukuran yang dikehendaki. Selanjutnya batang rotan tersebut dirunti, yaitu membersihkan rotan dari selaput larsik yang melekat pada permukaan batang, sehingga warna rotan menjadi mengkilat. Rotan yang telah mengalami peruntian tersebut disebut rotan asalan".

\section{Bahan dan Perkakas Membuat} Perabotan Rumah

Menurut Soedjono (1997 : 13) dalam bukunya yang berjudul "Seri kreatif dan terampil berkreasi dengan rotan", menjelaskan bahwa : Bahanbahan dan perkakas untuk keperluan mengerjakan perabotan rumah dari rotan antara lain : alat ukur, alat pembelahan, alat pemotong, alat pelubang, alat perata dan penghalus, alat pemukul dan tang, serta anglo atau kompor.

\section{Cara Menganyam Rotan}

Menurut Margono (1992 : 54) dalam bukunya yang berjudul "Ketrampilan anyaman bambu dan rotan", menjelaskan bahwa : "Bahan anyaman rotan setelah kita potongpotong menurut ukuran tertentu dalam keadaan kering, sebelum kita kerjakan, kita rendam dalam air hangat selama 15 menit, supaya lembek dan mudah dianyam". 
Beberapa cara anyaman rotan yang banyak dipakai antara lain :

anyaman belitan, anyaman belitan bertukar, anyaman belitan rangkap, anyaman belitan bertukar rangkap, anyaman tunggal, anyaman rangkap, anyaman penguat, anyaman tegak, anyaman tali.

\section{Motif/Corak Anyaman Rotan}

Anyaman rotan dengan berbagai macam motif/corak dirancang oleh pengrajin rotan secara turun-temurun berdasarkan tradisi nenek moyang. Sedangkan motif/corak anyaman dengan kreasi baru merupakan pengembangan dari motif/corak anyaman rotan yang sudah ada sebelumnya. Tidak semua motif/corak anyaman rotan memiliki nama, dan nama pada motif/corak anyaman rotan pun biasanya menggunakan istilah yang berbeda dari pengrajin rotan di setiap daerah. Beberapa contoh motif/corak anyaman rotan dan namanya antara lain : motif/corak anyaman rotan klasik, antik, dan kelabang, motif/corak anyaman rotan dekoratif geometris, geometris, dan tradisi, motif/corak anyaman rotan jruna kembar besar, jruno kembar kecil, dan silang ghedek, motif/corak anyaman rotan liris antik, liris, dan lampitan.

\section{Proses Finishing}

Keindahan rotan tidak hanya sekedar ada pada anyaman dan bentuknya saja, finishing pada rotan juga dapat membuat rotan menjadi modern dan menambah nilai estetika pula. Pada tahun 1970-an, kursi rotan hanya terbatas pada warna-warna alami rotan saja. Tetapi, kini warna rotan lebih bervariasi dengan warna fancy dan cenderung kehijau-hijauan, cokelat tua, hitam, putih, abu-abu, kecoklatan, kuning, dan krem. Proses finishing pada kursi rotan tidak jauh berbeda dengan proses finishing pada kayu. Hal yang perlu diperhatikan yaitu membersihkan permukaannya dari debu, minyak, lilin (wax), dan mengurangi kandungan air pada rotan dengan cara pemanasan. Finishing pada kursi rotan dapat dilakukan dengan cara : natural coating, stain, fancy colour, water based glaze.

\section{Kerangka Konseptual}

Anyaman dapat diartikan sebagai pekerjaan menganyam, dengan cara menyilang-nyilangkan lembaran pita secara teratur dan berulang-ulang atau menyusup-nyusupkan antara iratan lusi dan iratan pakan. Iratan lusi adalah benang atau lembaran yang membujur pada barang anyaman atau tenunan. Adapun anyaman yang terdapat pada masyarakat Kota Medan adalah berbagai produk rumah tangga, yang digunakan dalam kegiatan sehari-hari sebagai tempat duduk, dan lain-lain. Dalam hal ini, bahan yang digunakan dalam produk kerajinan anyam ini adalah rotan. Bentuk desain pada produk kerajinan anyam rotan di Kota Medan sangat beragam.

Berikut skema kerangka konseptual dari penelitian tentang tinjauan terhadap proses pembuatan kerajinan anyam rotan berdasarkan bentuk desain di Kota Medan. 


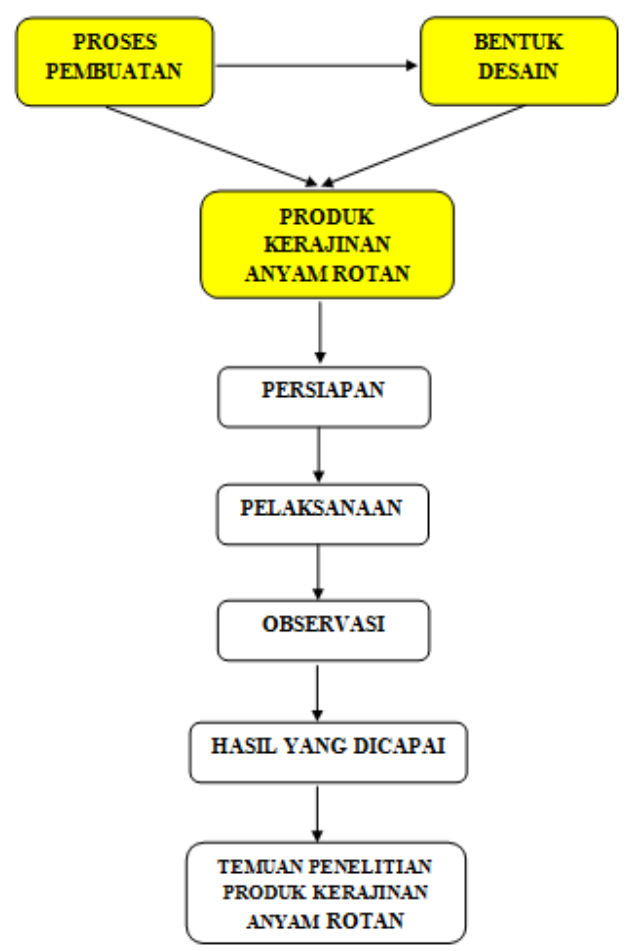

Gambar 2.80. Tinjauan Terhadap Proses Pembuatan Kerajinan Anyam Rotan Berdasarkan

Bentuk Desain di Kota Medan (Sumber : Erwin Crismianto, 2015)

\section{METODOLOGI PENELITIAN}

\section{Tempat, Waktu Penelitian, Populasi, dan Sampel}

Penelitian ini dilaksanakan di Jln. Titipapan Gg. Pertama No. 15 K, Gatot Subroto, Medan, tepatnya di Industri Kerajinan Anyam Rotan "Yogja". Waktu yang dibutuhkan untuk menyelesaikan penelitian ini adalah 8 (delapan) bulan terhitung setelah seminar proposal dilaksanakan, yaitu pada minggu ke tiga bulan maret 2016 s/d minggu ke tiga bulan November 2016. Populasi yang akan dijadikan sebagai objek dalam penelitian ini adalah seluruh produk kerajinan anyam rotan di industri kerajinan anyam rotan "Yogja" yang berada di Jln. Titipapan Gg. Pertama No. 15 K, Gatot Subroto, Medan. Sedangkan sampel dalam penelitian ini berjumlah 5 (lima) jenis produk kerajinan anyam rotan, dimana setiap jenis tersebut diambil sampel satu produk, karena desain produk pada setiap jenisnya adalah sama, yaitu penyekat ruangan, kursi dan meja tamu, kursi anak-anak, kursi goyang anak-anak, dan keranjang buah. Pengambilan sampel pada penelitian ini, menggunakan teknik sampel bertujuan atau purposive sampling, yaitu pengambilan sampel disesuaikan dengan kriteria yang telah ditentukan dan dianggap sesuai dengan kebutuhan peneliti (Arikunto, 2006 : 141).

\section{Metode Penelitian}

Penulis akan mendeskripsikan hasil dari data-data yang dikumpulkan di lapangan berdasarkan instrumen serta populasi dan sampel yang telah ditentukan. Penulis akan melakukan observasi pada awal penelitian untuk mengetahui permasalahan yang akan dibahas yaitu dengan melakukan pengamatan langsung ke lapangan, selanjutnya data yang diperoleh dari metode yang digunakan untuk menjawab rumusan masalah penelitian dilakukan dengan metode analisis deskriptif kualitatif. 


\section{Desain Penelitian}

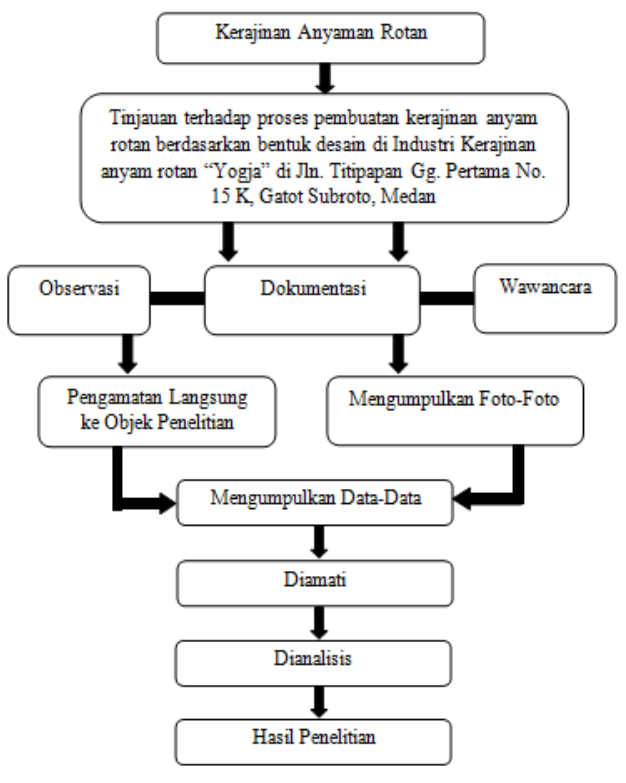

Gambar 3.1. Tinjauan terhadap proses pembuatan kerajinan anyam rotan berdasarkan bentuk desain di Kota Medan

(Sumber : Erwin Crismianto, 2015)

\section{Instrumen Penelitian dan Teknik Pengumpulan Data}

Instrumen merupakan sebuah alat untuk mendapatkan data. Dalam penelitian ini, Alat bantu yang digunakan peneliti untuk mengumpulkan data dan untuk memperoleh data penelitian tentang tinjauan terhadap proses pembuatan kerajinan anyam rotan berdasarkan bentuk desain di industri kerajinan anyam rotan "Yogja" yang terletak di Jln. Titipapan Gg. Pertama No. 15 K, Gatot Subroto, Medan ini adalah catatan observasi, tustel/kamera dan daftar wawancara. Sedangkan teknik pengumpulan data, untuk memperoleh data serta informasi yang dibutuhkan, digunakan teknik pengumpulan data sebagai berikut : observasi, dokumentasi, dan wawancara atau Interview.

\section{Teknik Analisis Data}

Teknik analisis data adalah suatu teknik yang digunakan untuk menentukan dan merupakan suatu penjelasan tentang sesuatu yang ada dalam penelitian. Dalam penelitian ini teknik analisis data yang digunakan oleh peneliti adalah analisis deskriptif kualitatif yaitu dengan membuat deskripsi atau sgambaran yang sejelas-jelasnya dan menguraikan teori dan data mengenai objek yang akan diteliti, berdasarkan data yang ada dan menerangkan data sesuai dengan fakta yang ada di lapangan (Sugiyono, $2010: 8$ ).

\section{HASIL PENELITIAN DAN PEMBAHASAN}

\section{Hasil Penelitian}

\section{Data Penelitian}

Hasil penelitian menunjukkan bahwa data yang ditemukan di lapangan pada penelitian ini ada 5 (lima) jenis produk kerajinan anyam rotan, dimana setiap jenis tersebut diambil sampel satu produk, karena desain produk pada setiap jenisnya adalah sama, yaitu penyekat ruangan, kursi dan meja tamu, kursi anak-anak, kursi goyang anak-anak, dan keranjang buah. Berikut ini adalah 5 (lima) jenis produk kerajinan anyam rotan di industri kerajinan anyam rotan "Yogja": 

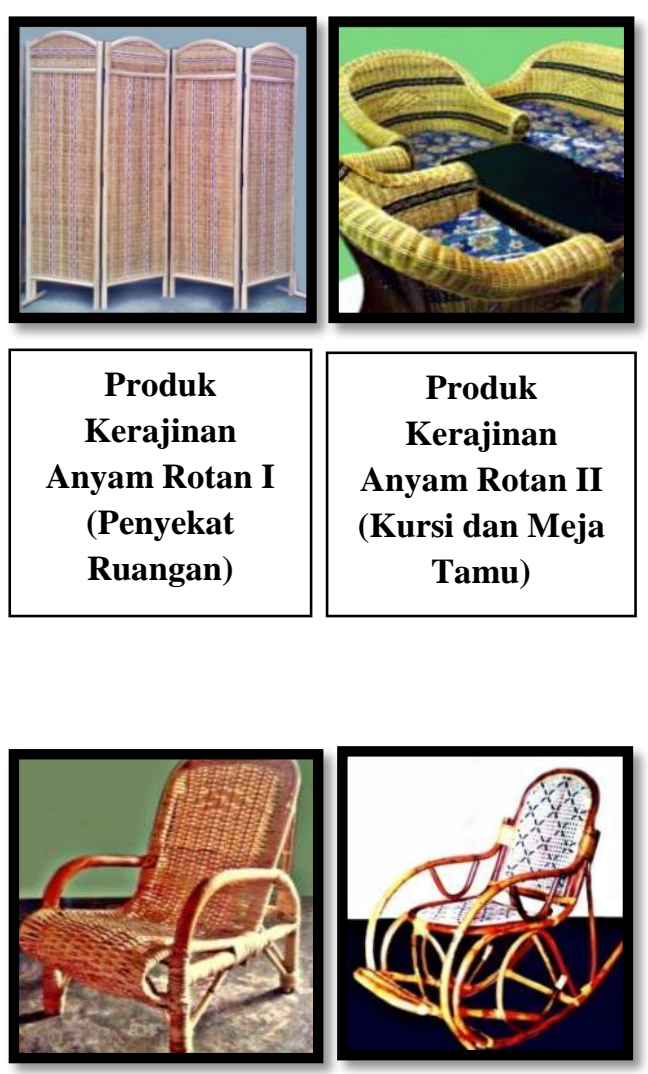

Produk

Kerajinan

Anyam Rotan

III (Kursi AnakAnak)

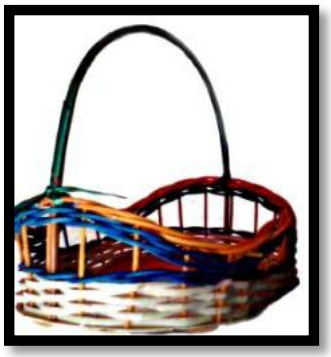

Produk

Kerajinan

Anyam Rotan V

(Keranjang

Buah)

Gambar Produk Kerajinan Anyam Rotan Penyekat Ruangan, Kursi dan Meja Tamu, Kursi Anak-Anak, Kursi Goyang Anak-Anak, dan Keranjang Buah (Sumber Foto : Erwin Crismianto, 2016)

\section{Analisis Hasil Penelitian}

Produk kerajinan anyam rotan yang diteliti berjumlah 5 (lima) produk, dibuat dengan proses pembuatan yang sama, melalui tujuh tahap, yaitu tahap pertama; proses penentuan ide produk kerajinan anyam rotan; tahap ke dua, yaitu proses pembuatan desain bentuk produk kerajinan anyam rotan; tahap ke tiga, yaitu persiapan bahan, meliputi bahan pokok dan bahan tambahan; tahap ke empat yaitu persiapan alat, yaitu : bor listrik besar, gunting rotan, bor listrik kecil, martil, staples, alat untuk meluruskan rotan; tahap ke lima yaitu proses pembuatan kerangka produk kerajinan anyam rotan; tahap ke enam yaitu proses menganyam rotan; dan tahap ke tujuh yaitu proses finishing, hanya saja pada proses pembuatan produk kerajinan anyam penyekat ruangan ada sedikit perbedaannya yaitu proses membersihkan atau memutihkan rotan setelah dianyam. Pembersihan atau Pemutihan rotan bertujuan untuk menghilangkan silika (bersifat kimia). Pemutihan rotan dilakukan dengan cara menyiramkan zat pemutih pada rotan yaitu air kaca ditambah dengan air biasa, dan H2O. Proses pembuatan anyaman keranjang buah juga ada sedikit perbedaannya yaitu proses pewarnaan rotan dilakukan di awal yaitu sebelum proses penganyaman keranjang buah. Bentuk desain dalam pembuatan produk kerajinan anyam rotan "Yogja" dibuat berdasarkan bentuk, ukuran, motif/corak dan dari bahan apa produk tersebut akan dibuat. Pembuatan desain ini dapat juga disesuaikan dengan desain permintaan konsumen. 


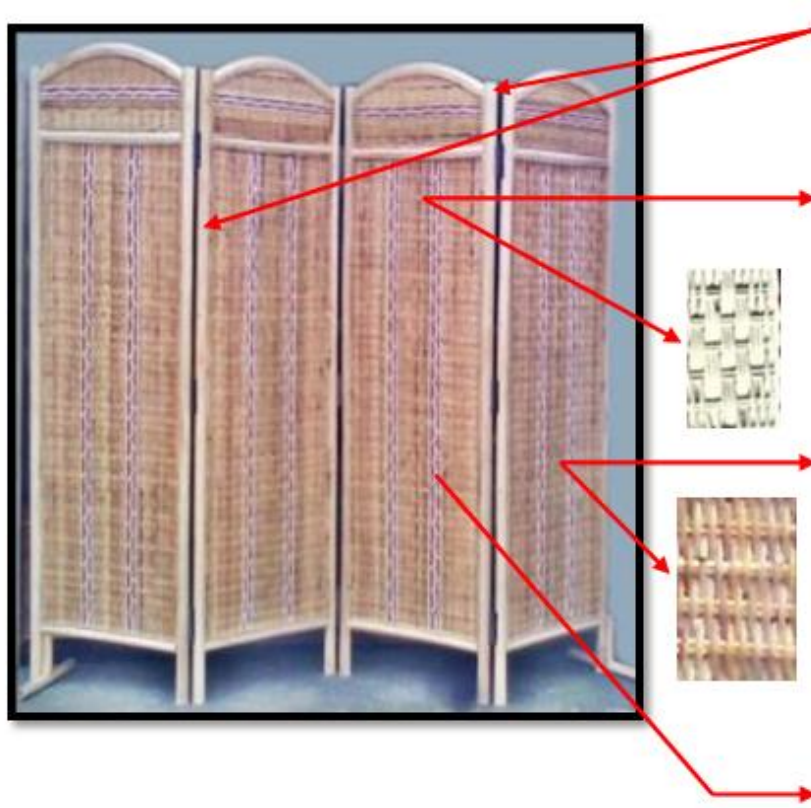

Rotan Manau (Calamus Manan Miq) digunakan untuk kerangka penyekat ruangan

Motif tambahan yang dibuat yaitu motif/corak anyaman rotanjiuna kembar besar, dan motif ini tercipta karena adanya teknik anyaman rangkap

Desain motif/corak anyaman pada penyekat ruangan ini adalah motif tradisi, dan menggunakan kulit rotan sega, serta rotan sintetis, dan motifini tercipta karena adanya teknik anyaman tunggal

Rotan Sintetis

Gambar 4.9. Analisis Produk Kerajinan Anyam Rotan I (Penyekat Ruangan) (Sumber : Erwin Crismianto, 2016)

\section{Analisis Produk Kerajinan Anyam Rotan II (Kursi dan Meja Tamu)}

\section{A. Kursi Tamu}

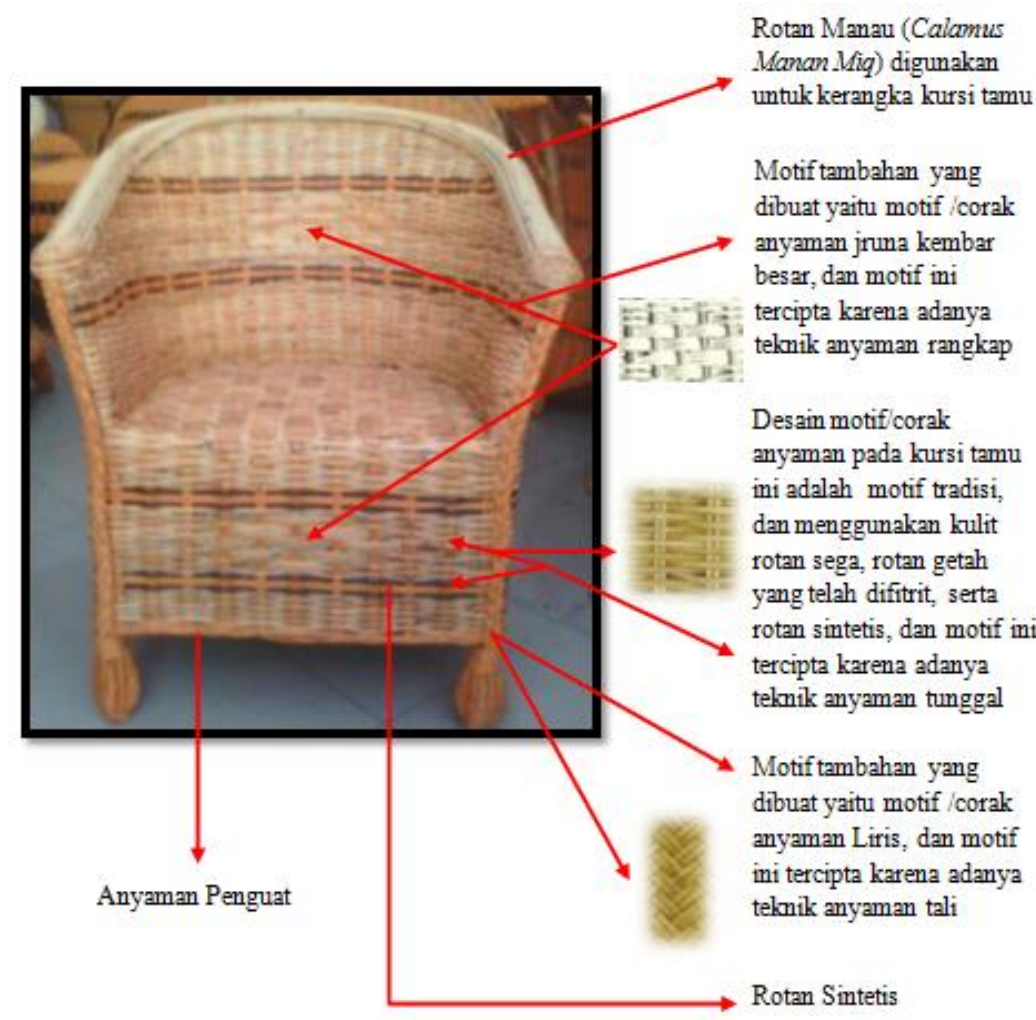

Gambar 4.34. Analisis Produk Kerajinan Anyam Rotan II (Kursi Tamu) (Sumber : Erwin Crismianto, 2016) 


\section{B. Meja Tamu}

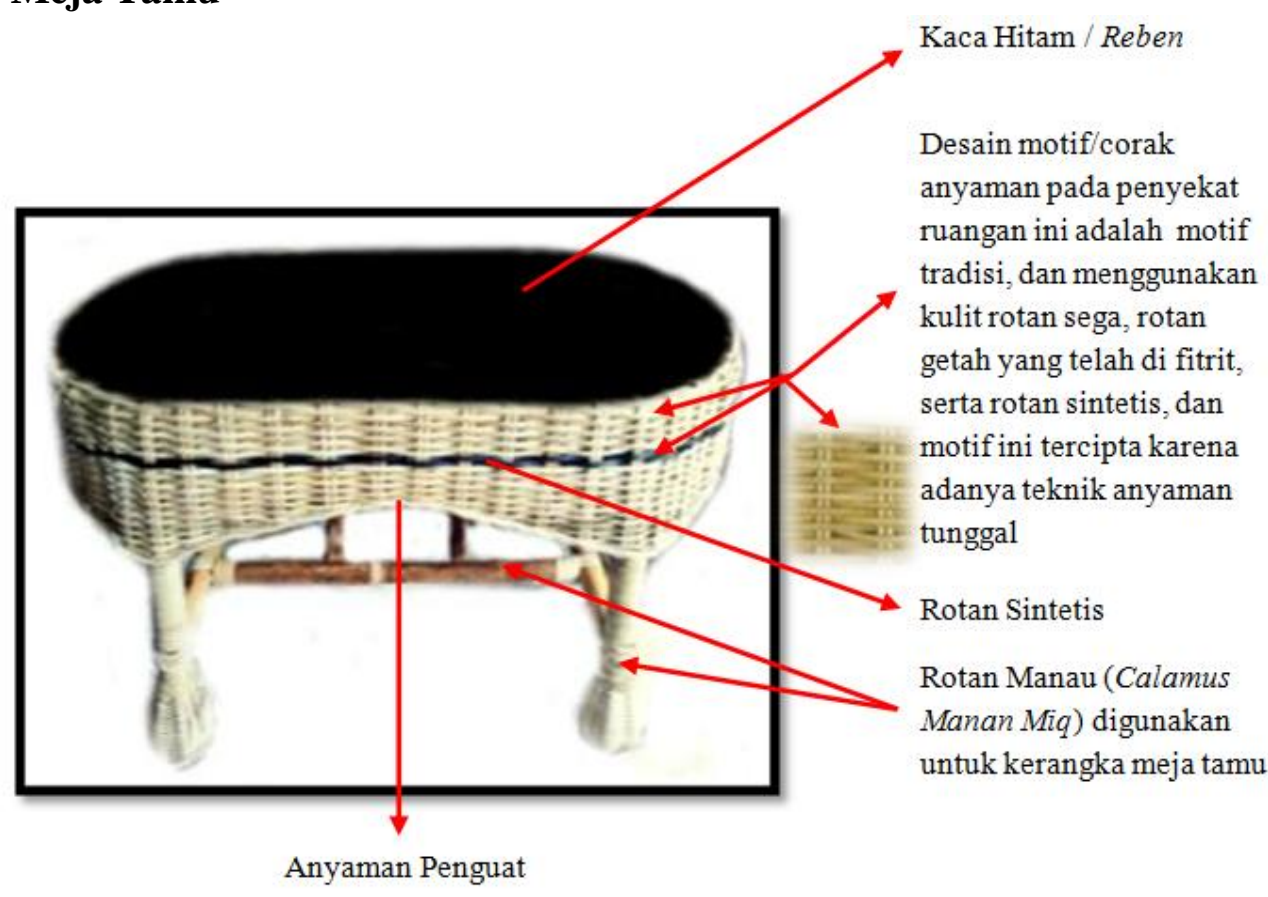

Gambar 4.35. Analisis Produk Kerajinan Anyam Rotan II (Meja Tamu)

(Sumber : Erwin Crismianto, 2016)

\section{Analisis Produk Kerajinan Anyam Rotan III (Kursi Anak-Anak)}

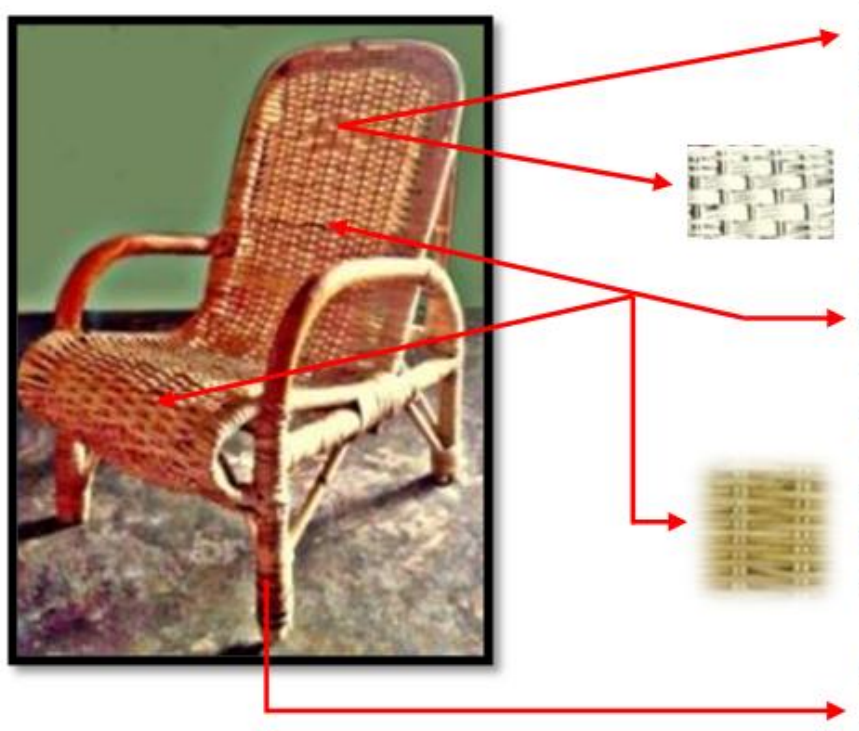

Motif tambahan yang dibuat yaitu motif/corak anyaman rotan jruna kembar besar, dan motif ini tercipta karena adanya teknik anyaman rangkap

Desain motif/corak anyaman pada kursi anak-anak ini adalah motif tradisi, dengan menggunakan kulit rotan sega, serta rotan getah yang telah difitrit, dan motif ini tercipta karena adanya teknik anyaman tunggal

Rotan Manau (Calamus Manan Miq) digunakan untuk kerangka kursi anak-anak

Gambar 4.66. Analisis produk kerajinan anyam rotan III (Kursi Anak-Anak) (Sumber : Erwin Crismianto, 2016) 


\section{Analisis Produk Kerajinan Anyam Rotan IV (Kursi Goyang Anak-Anak)}

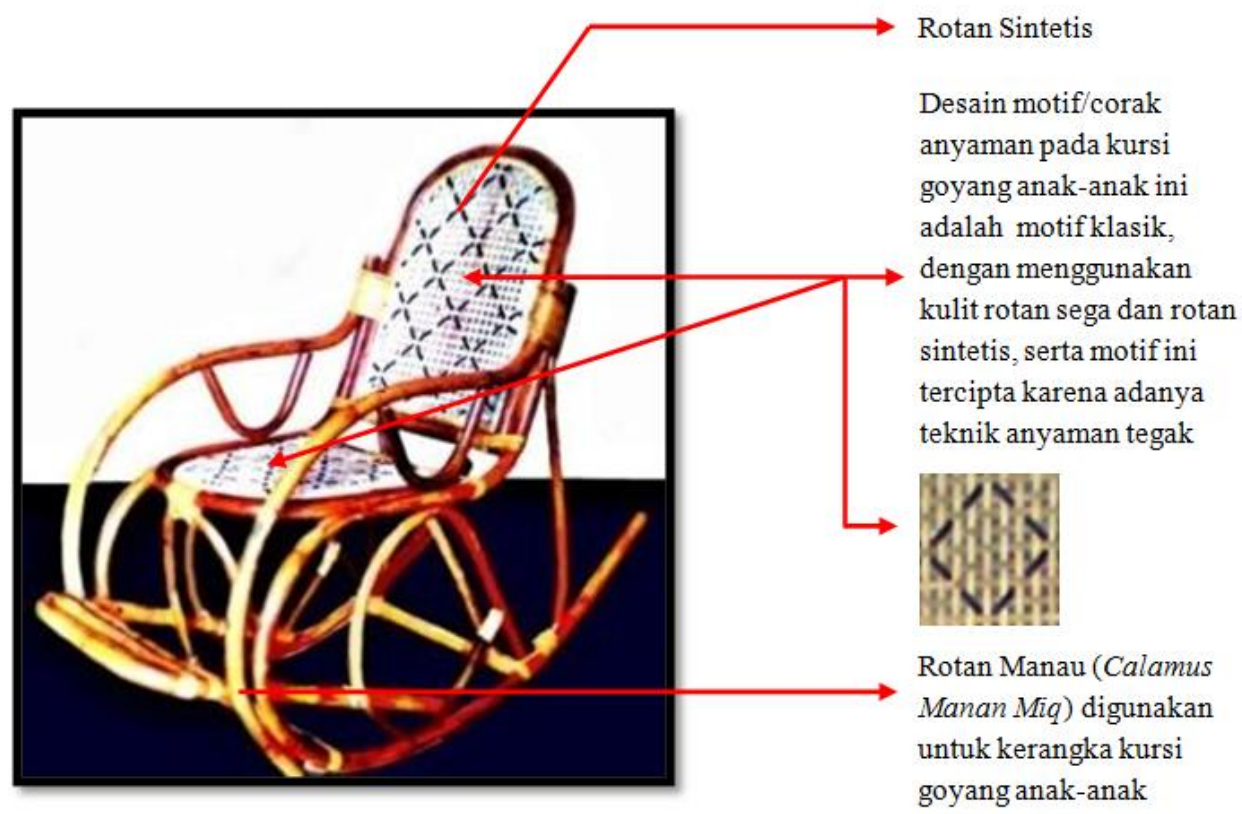

Gambar 4.71. Analisis produk kerajinan anyam rotan IV (Kursi Goyang Anak-Anak) (Sumber : Erwin Crismianto, 2016)

\section{Analisis Produk Kerajinan Anyam Rotan V (Keranjang Buah)}

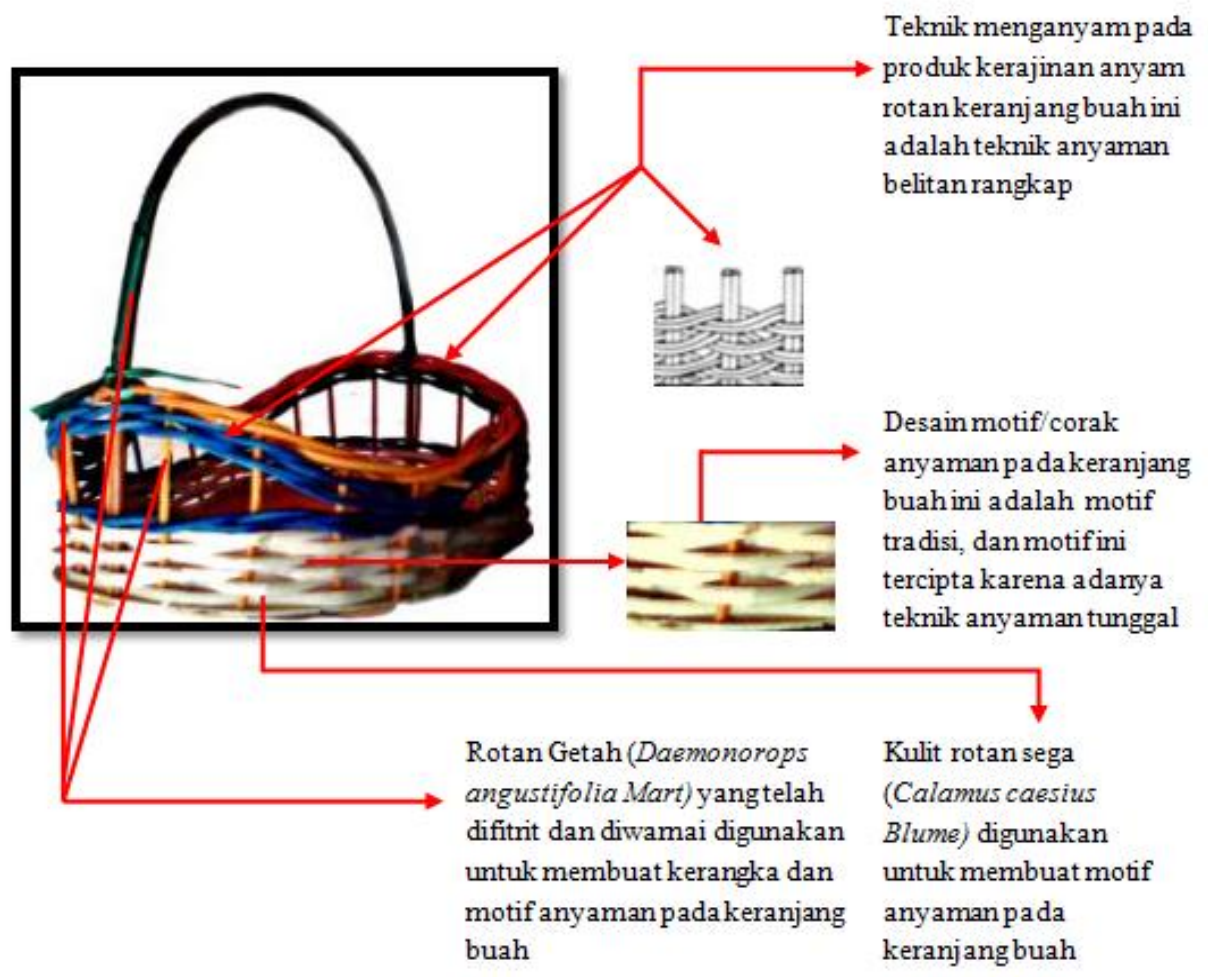

Gambar 4.75. Analisis produk kerajinan anyam rotan V (Keranjang Buah) (Sumber : Erwin Crismianto, 2016) 


\section{Pembahasan}

Seiring dengan perubahan dan perkembangan zaman, tuntutan atau kebutuhan masyarakat akan kerajinan semakin beragam, menyebabkan perlunya melakukan pengembangan kerajinan. Para pengrajin mulai memikirkan masalah-masalah yang timbul dalam proses produksi kerajinan, agar kelangsungan dan perkembangan produk kerajinan tetap terjaga dengan baik. Pengembangan desain atau produk kerajinan merupakan salah satu alternatif untuk memenuhi tuntutan pasar dan persaingan di pasar global yang semakin tajam. Pengembangan desain dibutuhkan untuk mengantisipasi tuntutan standar kualitas selera konsumen yang berubah-ubah dan perkembangan zaman. Namun, desain tidak selalu diawali oleh permintaan pasar, tetapi dapat juga dikarenakan munculnya inovasi atau kreasi baru, karena adanya penelitian dan pengembangan teknologi yang akan mempengaruhi pasar itu sendiri. (http://itbcentrallibrary.strategi.ac.id, diakses : Sabtu, 18 Februari 2017, Pukul : 19:00). Jika produk kerajinan anyam rotan sudah memiliki nilai estetis dan desain yang variatif, kreatif, dan inovatif, maka produk kerajinan anyam rotan dapat bersaing dengan produk lain, terutama produk rotan sintetis.

Berdasarkan penjelasan tersebut di atas, dapat disimpulkan bahwa nilai estetis suatu produk kerajinan anyam rotan akan tercipta dengan terpenuhinya unsur keindahan bentuk atau desain yang lebih variatif, kreatif, dan inovatif pada suatu produk.
Hasil dari pengolahan kerajinan anyam rotan selain memiliki nilai praktis yang dapat digunakan manusia dalam kehidupan seharihari, juga memiliki nilai estetis di dalamnya. Nilai estetis pada kerajinan dapat dilihat dari kualitas produk yang telah dibuat, seperti bentuk dan performannya, kenyamanan, dan keawetannya. Nilai estetis dalam kerajinan anyam rotan ditentukan oleh pengorganisasian unsur-unsur desain dan prinsipprinsip desain. Jika nilai estetis sudah terpenuhi, dan desain sudah variatif, kreatif, dan inovatif, maka produk kerajinan anyam rotan sudah pasti dapat bersaing dengan produk lain terutama rotan sintetis. Produk kerajinan anyam rotan alami sangat bisa bersaing dengan produk berbahan rotan sintetis, karena lebih awet, dan barang-barang rumah tangga yang berasal dari anyaman rotan alami sesungguhnya akan lebih tahan lama dibanding barang-barang rumah tangga yang terbuat dari busa atau bahan sintetis lain, seperti sofa. Daya tahan anyaman rotan alami memang tidak diragukan lagi, sebab rotan alami memang dikenal sebagai tumbuh-tumbuhan yang memiliki daya tahan cukup lama.

\section{Temuan Penelitian}

Dari hasil pengolahan data yang diperoleh dari berbagai instrumen penelitian dan sampai pada analisis data, penelitian ini menunjukkan beberapa temuan antara lain:

1. Penulis melihat, proses pembuatan dan bentuk desain kerajinan anyam rotan di industri kerajinan anyam rotan "Yogja" masih tergolong sederhana, 
dikarenakan desain pada produk kerajinan anyam rotan ini masih menggunakan pengulangan dari bentukbentuk desain yang sudah ada, sehingga produk yang dihasilkan pun masih sederhana dan merupakan bentuk-bentuk lama.

2. Penulis melihat, desain dari produk kerajinan anyam rotan di industri kerajinan anyam rotan "Yogja" dibuat oleh pemilik industri dan pengrajin rotan. Desain ini dibuat berdasarkan pesanan atau permintaan konsumen, dan ada juga desain yang dibuat berdasarkan ide dari pemilik industri dan pengrajin. Desain yang dibuat masih berdasarkan bentukbentuk lama, sehingga kurang variatif.

3. Penulis melihat, produk kerajinan anyam rotan tersebut sudah memenuhi prinsip-prinsip desain dan sudah dapat menghadirkan nilai estetis, sehingga meningkatkan kuantitas dan kualitas produk kerajinan anyam rotan di industri kerajinan anyam rotan "Yogja".

4. Rotan yang dipakai pada produk kerajinan anyam rotan di industri kerajinan anyam rotan "Yogja" yaitu Rotan manau (untuk kerangka), kulit rotan sega, dan rotan getah yang telah di fitrit/diperkecil (untuk membuat anyaman agar menghasilkan motif anyaman), serta bahan tambahan yaitu rotan sintetis yang juga digunakan untuk membuat motif anyaman.

5. Penulis melihat, pemilihan motif/corak pada produk kerajinan anyam rotan di industri kerajinan anyam rotan "Yogja" hanya menerapkan sedikit motif, yaitu motif tradisi, motif jruna kembar besar, motif liris, dan motif klasik.

6. Penulis melihat, Proses finishing yang diterapkan pada produk kerajinan anyam rotan di industri kerajinan anyam rotan "Yogja" hanya satu jenis yaitu natural coating.

7. Penulis melihat, teknik yang digunakan pada produk kerajinan anyam rotan di industri kerajinan anyam rotan "Yogja" masih sederhana dan masih menggunakan cara tradisional, dan masih erat kaitannya dengan desain, teknik, dan motif-motif lama. Teknik tersebut yaitu teknik anyaman tunggal, teknik anyaman rangkap, teknik anyaman tali, dan teknik anyaman tegak. 
PENUTUP

\section{Simpulan dan Saran}

\section{A. Simpulan}

Berdasarkan tinjauan dan analisis yang telah dilakukan terhadap subjek penelitian yaitu produk kerajinan anyam rotan di industri kerajinan anyam rotan "Yogja", maka beberapa hal yang dapat disimpulkan pada penelitian ini adalah :

1. Proses pembuatan produk kerajinan anyam rotan di industri kerajinan anyam rotan "Yogja" secara garis besar yaitu dilakukan melalui tujuh tahap, yaitu tahap pertama; proses penentuan ide produk kerajinan anyam rotan; tahap ke dua, yaitu proses pembuatan desain bentuk produk kerajinan anyam rotan; tahap ke tiga, yaitu persiapan bahan, meliputi bahan pokok dan bahan tambahan; tahap ke empat yaitu persiapan alat; tahap ke lima yaitu proses pembuatan kerangka produk kerajinan anyam rotan; tahap ke enam yaitu proses menganyam rotan; dan tahap ke tujuh yaitu proses finishing. Proses ini merupakan proses pembuatan lima produk yang diteliti yaitu penyekat ruangan, kursi dan meja tamu, kursi anakanak, kursi goyang anakanak, dan keranjang buah. Produk ini dibuat dengan proses pembuatan yang sama, hanya saja pada proses pembuatan produk kerajinan anyam rotan penyekat ruangan, ada sedikit perbedaannya yaitu adanya proses membersihkan atau memutihkan rotan setelah dianyam, yang bertujuan untuk menghilangkan silika (bersifat kimia). Pemutihan rotan dilakukan dengan cara menyiramkan zat pemutih pada rotan yaitu air kaca ditambah dengan air biasa, dan H2O. Proses pembuatan anyaman keranjang buah juga ada sedikit perbedaannya yaitu proses pewarnaan rotan, yang dilakukan di awal yaitu sebelum tahap proses penganyaman keranjang buah.

2. Bentuk desain produk kerajinan anyam rotan di industri kerajinan anyam rotan "Yogja" dilakukan untuk menentukan gambaran atau rancangan yang jelas, dengan menggambarkan desain tersebut pada kertas kerja mengenai bentuk, ukuran, motif/corak dan dari bahan apa produk tersebut akan dibuat. Pembuatan desain ini dapat juga disesuaikan dengan desain permintaan konsumen. Penerapan desain, pemilihan motif/corak, finishing, dan teknik yang digunakan masih sederhana, dan masih menggunakan pengulangan dari bentuk-bentuk lama, sehingga kurang variatif. Namun, produk kerajinan anyam rotan tersebut sudah memenuhi prinsip-prinsip desain dan sudah dapat menghadirkan nilai estetis, 
sehingga meningkatkan kuantitas dan kualitas produk kerajinan anyam rotan di industri kerajinan anyam rotan "Yogja".

\section{B. Saran}

Berdasarkan simpulan dari hasil penelitian, maka penulis memberikan beberapa pendapat dan saran sebagai berikut :

1. Bagi para pengusaha atau pengrajin rotan agar dapat mengembangkan kerajinan anyaman rotan dengan bentuk desain, teknik, dan motif/corak yang lebih variatif, kreatif dan inovatif, agar menambah nilai estetis, serta mampu melestarikan kerajinan anyaman rotan tanpa meninggalkan keaslian ciri khas dari pengolahan rotannya.

2. Bagi Industri kerajinan anyaman rotan "Yogja" untuk lebih memperkaya desaindesain kerajinan anyaman rotan agar tidak monoton, dan menciptakan desain-desain baru yang lebih variatif, kreatif, inovatif, dan berkualitas.

3. Bagi Industri kerajinan anyaman rotan "Yogja" untuk memperluas jangkauan penjualan, disarankan untuk membuat website, blog, atau media sosial.

4. Bagi Departemen

Perindustrian dan Perdagangan hendaknya dapat melengkapi sarana dan prasarana yang kurang lengkap dalam menunjang kegiatan pembuatan kerajinan anyaman rotan dan memberikan pembinaanpembinaan serta workshop pada sentra-sentra pengrajin anyaman rotan yang telah ada serta memantau perkembangan kelestarian kerajinan anyaman rotan di Kota Medan dan sekitarnya dalam mempertahankan ciri produk kerajinannya, serta tidak lupa pula memperkenalkan kerajinan anyaman rotan ke daerah lainnya supaya keberadaannya dapat dikenal luas.

Harapan penulis, hendaknya penelitian ini dilanjutkan dan dikembangkan pada ruang lingkup yang lebih luas lagi sehingga dapat memberikan manfaat yang berarti bagi dunia perindustrian, khususnya industri kerajinan anyam rotan, dan dunia pendidikan pada umumnya.

\section{DAFTAR PUSTAKA}

Arikunto, Suharsimi. 2013. Prosedur Penelitian. Jakarta: Rineka Cipta.

Armada. 2012. Tinjauan Terhadap Proses, Fungsi, Motif, Dan Warna Kerajinan Anyam Ampang Di Kecamatan Blangpegayon Kabupaten Gayo Lues Provinsi Nanggroe Aceh Darussalam. Skripsi. Medan: Fakultas Bahasa dan Seni Universitas Negeri Medan. 
Chairani. 2012. Kerajinan Anyam.

Medan : Jurusan Seni Rupa

FBS Unimed.

De Lopatecki, Eugene. 1952. Advertising Layout and Typography. United States Of America- Newyork : The Ronald Press Company.

Dharsono (Sony Kartika) dan Sunarmi. 2007. Estetika Seni Rupa Nusantara. Surakarta.

Ellsworth, Maud. 1957. Art For The High School. United States Of America: The L. W. Singer Company, Inc.

Fitriany, Detty, Jamaludin dan Irsalina Adani. 2013. Desain Kursi Berbahan Baku Rotan dari Masa Ke Masa. Jurnal Online Institut Teknologi Nasional Bandung : Vol. 01 (01) 1-13, Bandung.

Irawan, Bambang dan Priscilla Tamara. 2013. Dasar-Dasar Desain. Jakarta :Griya Kreasi.

Kalima, Titi dan Sumarhani. 2015. Identifikasi Jenis-Jenis Rotan pada Hutan Rakyat di Katingan, Kalimantan Tengah dan Upaya Pengembangan. Jurnal Pros Sem Nas Masy Biodiv Indon: Vol. 01 (02) 194-200, Bogor.

Margono, G. 1992. Keterampilan Anyaman Bambu dan Rotan. Semarang: Aneka Ilmu.
Murtihadi dan G. Gunarto. 1982. Dasar-Dasar Desain. Jakarta: Departemen Pendidikan dan Kebudayaan.

Muzakki, Akhmad. 2014. Imaji. Jurnal Seni Rupa: FBS UNY: Vol. 12 (02) 29-38, Yogyakarta.

Naibaho, Togarma dan Wegig Murwonugroho. 1998. Metodologi Riset Seni Rupa dan Desain. Jakarta: Universitas Trisakti.

Pasaribu, Mangatas. 2008. Posisi Keindahan Dalam Seni. Jurnal Seni Rupa: FBS Unimed : Vol. 05 (1) 31-38, Medan.

Pusat Pembinaan dan Pengembangan Bahasa. 1996. Kamus Besar Bahasa Indonesia (edisi 2 cetakan ke tujuh). Jakarta : Balai Pustaka.

Retnoningsih, Ana dan Suharsono. 2005. Kamus Besar Bahasa Indonesia, Semarang : CV. Widya Karya.

Sachari, Agus. 1986. Desain Gaya dan Realitas. Jakarta: Rajawali.

Sachari, Agus. 2005. Metodologi Penelitian Budaya Rupa. Jakarta : Erlangga. 
Sachari, Agus dan Yan Yan Sunarya. 2002. Sejarah dan Perkembangan Desain \& Dunia Kesenirupaan di Indonesia. Bandung: Penerbit ITB.

Saraswati. 1994. Seni Anyaman Hati Batang Rotan (Pitrit). Jakarta: Bhratara.

Sari, Dwi Oktaria dan Nyimas Wardah. 2016. Panduan dan Laporan Kegiatan Pembuatan Furnitur Berbahan Dasar Rotan. Palembang : Biodiversity and Climate Change Project (BIOCLIME).

Soedjono. 2000. Seri Kreatif dan Terampil : Berkreasi dengan Rotan. Bandung : Remaja Rosdakarya.

Soedjono, dan E. Srinuryani. 1991. Seri Pengrajin Terampil dan Kreatif : Kerajinan Rotan. Bandung: Angkasa.

Soedjono, H. Hartanto. 1997.

Mengolah Rotan untuk Barang Kerajinan Ekspor. Semarang : Dahara Prize.

Suciati dan Isfarudi. 1997. Metode Penelitian. Jakarta : Universitas terbuka.

Sugiyono, 2010. Metode Penelitian Kuantitatif, Kualitatif dan $R \& D$. Bandung : Alfabeta.
Ulandari, Octavia. 2014. Bentuk Kue Tradisional Sumatera Utara Sebagai Inspirasi Penciptaan Kartun. Jurnal Seni Rupa: FBS Unimed : Vol. 10 (02) 73-87, Medan.

http://agusriyanto09.wordpress.com (Diakses : Sabtu, 18 Februari 2017, Pukul : 17:00)

http://carajuki.com/unsur-unsur-senirupa/

(Diakses : Sabtu, 7 November 2015, Pukul : 02:00)

http://id.aliexpress.com/ diakses : Sabtu, 26 Desember 2015 pukul : 15:30

http:// itbcentrallibrary. strategi.ac.id (Diakses : Sabtu, 18 Februari 2017, Pukul : 19:00)

http://Pengembangan Desain Produk Kerajinan. Htm (Diakses : Sabtu, 18 Februari 2017, Pukul : 20:00)

http://teorionline,wordpress.com (Diakses : Kamis, 10 september 2015, Pukul : 04:37)

www.artikata.com

(Diakses : Kamis, 10 september 2015, Pukul : 04:37)

www.pengertianahli.com/2014/05/pe ngertian-produk-dan-jenisproduk.htmI?m=1 (Diakses : Sabtu, 7 November 2015, Pukul : 02:00) 